\title{
SELEÇÃO DE MÉTODOS DE ARMAZENAMENTO DE TECIDOS FOLIARES PARA EXTRAÇÃO DE DNA DE YACON
}

\author{
Felipe Menine ${ }^{1}$ \\ Rodrigo Monte Lorenzoni ${ }^{2}$ \\ Edilson Marques Júnior ${ }^{3}$ \\ Taís Cristina Bastos Soares ${ }^{4}$ \\ Fábio Luiz de Oliveira ${ }^{5}$
}

Resumo: A yacon vem se destacando devido aos efeitos promissórios para a saúde humana, gerando a necessidade de mais pesquisas sobre a espécie. Sendo assim, o objetivo da pesquisa foi avaliar diferentes formas de armazenamento de folhas de yacon para extração de DNA com qualidade para realização de análises moleculares. Foram testadas cinco formas de armazenamento dos tecidos foliares, com dez amostras por tratamento, sendo elas: Tecido foliar fresco (TFF), Tecido foliar congelado (TFC), Tecido foliar armazenado com sílica em geladeira (TFSG), Tecido foliar mantido por cinco dias com sílica em temperatura ambiente (TFSTA) e Tecido foliar mantido por cinco dias sem sílica em temperatura ambiente (TFTA). Para extração de DNA, em todos os tratamentos, foi utilizado o protocolo proposto por Doyle e Doyle (1990) com modificações. Em todos os tratamentos foi obtido quantidade de DNA suficiente para realização de análises moleculares, sendo que o melhor resultado foi obtido pelo tratamento TFF com 331,24ng e o menor valor foi oriundo do tratamento TFTA com 42,98ng.

Palavras-chave: Smallanthus sonchifolius; Compostos fenólicos; Relação 260/280 nm; PCR.

\footnotetext{
${ }^{1}$ Graduando em Agronomia da Universidade Federal do Espírito Santo (CCA-UFES), Brasil. E-mail: felipemarcatemenine@gmail.com.br.

2 Doutorando em Produção Vegetal - Biotecnologia, da Universidade Federal do Espírito Santo (CCA-UFES), Brasil. E-mail: rodrigomlorenzoni@gmail.com.

${ }^{3}$ Graduando em Agronomia da Universidade Federal do Espírito Santo (CCA-UFES), Brasil. E-mail: edilsonmarquesjr@hotmail.com.

${ }^{4}$ Professora adjunta da Universidade Federal do Espírito Santo (CCA-UFES), Brasil. E-mail: tcbsoares@yahoo.com.br.

${ }^{5}$ Professor adjunto da Universidade Federal do Espírito Santo (CCA-UFES). E-mail: fabiocapi@yahoo.com.br.
} 